\title{
World cup 2014: an analysis of the international media coverage
}

\begin{abstract}
The 2014 World Cup's legacy may be discussed in several areas, with consequences which go beyond the goals of one mere work and will only be fully understood in the long-term. The great investments on infrastructure, the wave of protests that took place in June 2013, Brazil's defeat and the image the World Cup left of the country are only some of the topics which shall be approached. The bequeathed image of the matches abroad was one of great distress for the government, as well as for the general population, worried about a possible legacy which would relate the country to misery, violence and disorder, determining in the long run Brazil's position in the international scenery. The country's image abroad is not only an important element in the framework of the international relations; it also operates in a way to define the country's self-perception, being an important way for the citizens to produce their own conceptions and branching out into several social areas, from the economy and politics to the culture.
\end{abstract}

Keywords: analysis, country, international, framework, position, legacy, economy, politics

\section{Introduction}

In the present paper we attempt to delineate how Brazil was perceived abroad during the period of the event. Therefore, the coverage of nine media outlets in three different languages was analyzed: BBC, CNN, The Guardian, The New York Times, Daily Mail, Le Monde, Le Figaro, El Pais and El Mundo, which published 699 articles about the most diverse themes regarding the Brazilian society. Thus, we seek to comprehend which were the most present characterizations of Brazil during the World Cup, as well as which types of prejudice and mystifications the foreign press would take from this event and which would be the possible changes that an event of such magnitude could offer for the country's image abroad.

\section{Sport mega-events}

Using sport events to promote a nation is almost as old as the events themselves, with the Olympic Games in Berlin in 1936 as prototype of the modern megaevents, used by the Nazi regime to show the superiority of the German state and the German folk. ${ }^{1}$ During the Cold War, the games were the perfect stage for the symbolic dispute between capitalism and communism, carried out respectively by the USA and the USSR. The sport events, however, have suffered great changes since the 80 s, caused by the nations' perception that hosting these events would be a means of promoting the country before the international scenery and improving the nation's image as a whole. Proof is that the IOC and FIFA found it difficult to define their headquarters during the first editions of the games, whereas today even nations which are more established in the international scenery, such as England and Germany, are willing to spend large volumes of money to host sport events. ${ }^{1,2}$ Sport megaevents nowadays show a strong popular appeal, reaching billions of people in every part of the world due to the innovations in the communications area. They are display windows for technological innovations in the most different sectors, and the opportunity for a country to show its conquests in the most various fields, from urban mobility to social security. ${ }^{3}$ Another important element for the growth of sport megaevents is the fact that sports may be one of the few elements that is shared almost in a universal way, with all the nations playing according to the same rules and values, attracting an almost universal public. ${ }^{1}$ In this new
Volume 3 Issue I - 2019

\author{
Marco Bettine \\ Department of Social Change and Political Participation, \\ University of Sao Paulo São Paulo, Brazil
}

\begin{abstract}
Correspondence: Marco Bettine, Department of Social Change and Political Participation, University of Sao Paulo São Paulo, Post doctor in Porto University-FADEUP, Brazil, Email marcobettine@gmail.com
\end{abstract}

Received: November 07, 2018 | Published: February 19, 2019 scenery, the sport megaevents present an opportunity for the country to promote its image for the world and reach a global audience through the universal values of the games. During the 2012 Olympic Games in London, analysts estimate that 3.6 billion people (more than half of the world population) watched, at least, one minute of the games. ${ }^{1}$

Starting from the announcement of the event, the host country will be in the spotlight of the international media, being a recurrent subject for the newscast of many countries. Topics, such as the progression of construction works, tourist security, expenses, delays and protests will be discussed almost on a daily basis. During the event itself, the world and the international mass media turn their attention to the country, which is going to be invaded by hordes of tourists. Although the main focus lies upon the sport, the global audience will eventually-even if indirectly-have contact with other aspects of the country, since the mega event, as previously discussed, is an opportunity for the nation to show itself to the world. This fact can be proven by the analysis of the search patterns of Google Trends, in our case, using the specific term "Brazil". Analyzing the word in each one of the considered languages, Brazil, Brasil and Brésil, we noticed that the search volume for the term during the event's period was $60 \%$ higher than the previous peak in English, 40\% higher in Spanish and 47\% higher in French. ${ }^{2}$

\section{The traveller's view and the Brazilian identity}

"The way we are seen is also a fundamental element for the definition of our own self-image, therefore understanding how this discourse is articulated is also important to understand our own vision of ourselves. ${ }^{4}$ In Brazil's case -and Latin America, in a wider manner -, this representation becomes more central for the construction of our identity. The foreigner's look will be present since the very first moment of our discovery, making it a decisive element for the construction of our self-image). ${ }^{5}$ In a first moment, the role of building this image is played by the guide books. Mostly written by travellers, missionaries and adventurers, this type of literature provides the European public, eager for stories of newly found lands, with the first

'http://www.olympic.org/Documents/IOC_Marketing/Broadcasting/ London_2012_Global_\%20Broadcast_Report.pdf

${ }^{2} \mathrm{http}: / /$ www.olympic.org/Documents/IOC_Marketing/Broadcasting/ London 2012 Global_\%20Broadcast_Report.pdff 
images of the new continent, building some myths, mainly regarding the nature, which persist until the present day. ${ }^{6}$ In the course of the centuries, these perceptions will also operate in a way to contribute to build the (mainly European) imaginary about the rest of the world. The adventurers will, while writing their stories, contribute to the promotion of prejudices and the construction of a eurocentric perception of the world, marked by the relationship between colony and metropole. ${ }^{?}$

It is worth mentioning that this group of narratives is neither homogeneous nor stable, given that it is made of a variety of often conflicting perceptions, which change in the course of time and in relation to each reader's interpretations. In a way, it is a phenomenon that continues to be repeated. If in the 18th century we had the figure of the adventurer bringing narratives of adventures in distant lands and contacts with exotic cultures, today we have the means of mass communication to play this role. ${ }^{8}$ In this sense, we can assume that, in terms of means of communication, the international correspondents play this role by conveying their world perception, alongside prejudices and mistakes about each place, in modern travel reports meant for a global audience. ${ }^{9}$

The World Cup, as we consider, is an important chapter for the construction of this image, an event that counted more than 20 thousand registered press professionals ( $80 \%$ foreigners), ${ }^{3}$ producing varied contents for the public, even if mostly focussed on the sport itself. Many analyzed about the role of the international correspondants in Brazil have been made, ${ }^{9,10}$ as well as about their influence on the construction of the nation's imaginary. However, we understand that the media coverage of the World Football Cup presents a series of new important elements, attracting a diverse range of professionals, limited not only by the international correspondants. They add new visions and interests and call the attention of a wider public, which is often not interested in the international news and now shows a momentary curiosity for the event's host country or even comes indirectly to this kind of news. The perception of the foreign press and, indirectly, of the more than 700 thousand international tourists who took part in the event ${ }^{4}$ was the source of a great distress for the national press, as well as for the general population, ${ }^{5}$ who recognized this moment as the key to delineate the perception of the country abroad and, thus, of the own Brazilian self-image.

\section{Research methodology}

In order to interpret the media coverage, $699(n=699)$ articles of nine English-, French- and Spanish-speaking newspapers-the most accessed ones in the internet during the period - were analyzed. The selection of these newspapers was made by the website Alexa, a company responsable for measuring Internet traffic which produces the ranking of the 500 most acessed websites in the world. The newspapers were: CNN (57th position), BBC (64th), Daily Mail (96th), The New York Times (126th), The Guardian (147th), El Pais (373rd), El Mundo (412th), Le Monde (445th) and Le Figaro (452nd). ${ }^{6}$ $\mathrm{T}$ he chosen analysis period was between June 11th and July 15th, i.e. three days before the opening cerimony of the 2014 World Cup

${ }^{3}$ http://www.abi.org.br/copa-do-mundo-no-brasil-tem-numero-recorde-dejornalistas-credenciados/

${ }^{4}$ http://esportes.r7.com/futebol/copa-do-mundo-2014/brasil-recebeu-1milhao-de-turistas-estrangeiros-durante-a-copa-14072014

${ }^{5} \mathrm{http}$ //veja.abril.com.br/noticia/esporte/para-9-entre-10-torcedores-copadeixara-imagem-negativa/

${ }^{6} \mathrm{http}: / /$ www.alexa.com/topsitesAccessed on June 10th, 2014 until three days after its end. As an exclusion criterion we used the country's non-participation during the World Cup, since it generates little interest in the local press, since the number of journalists and tourists of these countries is also lower. We chose these languages because they are considered the ones with the highest number of nonnative speakers, which means that these newspapers serve as source both for the readers of their respective countries, as well as for a great number of people who use these newspapers as an alternative information source.

Articles containing the keyword Brazil (Brasil, Brazil, Brésil) were selected. Subsequently, we chose the articles which dealt directly with the country, discarding the ones exclusively related to the sport (lesions, tactics, expectations about the players etc.). This filtering process resulted in 699 chosen articles, which were then separated into five different categories:

(1) Infrastructure: In this category we gathered the articles which showed concern regarding the Brazilian infrastructure, whether related to the World Cup or not. Not only did the newspapers approach the constructions related to the World Cup, such as airports, subway stations, hotels and tourist safety, but also they delved into other areas unrelated to the event, but still poor in Brazil, such as sewage disposal, highway network, healthcare and education.

(2) Social Indexes: The relation between Brazil, poverty and violence is recurring in the international and national media. In this category can be found articles that deal with themes related to the population's quality of life, such as, for example, inequality, social projects and access to justice.

(3) Culture: The perception of the cultural aspects of a country abroad is a key element for the international relations. In this category we gathered the articles regarding the several manifestations of what is Brazilian and Brazil's representations. Articles about music, folklore, gastronomy, literature and natural landscapes.

(4) Football: Brazil is known as the football's country. In this category were gathered articles which deal with the main role of the sport in the life of the Brazilians, mainly when the newspapers express the notion that football is more than a sport for the Brazilians.

(5) The Cup's Feasibility: Articles that express concern about the event's success and the support of the population regarding the event, by the example of several protests during the World Cup.

(6) Everyday life: In this category were gathered articles that deal with events unrelated to the World Cup and the previous categories, such as sensationalist articles, related to the interests of the newspaper's country rather than a perception of the country itself.

Sometimes the articles concern more than one category. In these cases, we chose only one in each article, privileging its most relevant meaning.

\section{Data assessment}

The analyzed articles contain an enormous variety of subjects and point of views, therefore any attempt to frame their role is not a pristine activity. We also acknowledge that the analyzed newspapers differ in their editorial management, format and target public; each one of them approaching the topics in its own manner, with its prejudices 
and its internal agenda. However, the purpose of this paper is neither to build a deepened analysis of each one of them, nor to attribute value about the newspapers' supposed journalistic "precision", but rather to understand which themes and approaches were more reoccurring and to conceive a wider picture about the World Cup in the foreign press. In this manner, we noticed a series of similar reoccurrences and approaches among the means of communication in the period, despite some exceptions. We shall firstly analyze the most reoccurring elements, so that we may subsequently discuss the coverage of each newspaper individually (Table 1).

In terms of the "event's success", recognizing the great volatility of this category and the source of great anxiety for the Brazilian population, towards the end of the event, we noticed an extremely positive perspective in the majority of the newspapers, which trace a similar path. In the beginning of the event, we also noticed a tendency of the communication vehicles to doubt its feasibility, showing concern about the infrastructure, protests, corruption, violence etc. During the incident-free course of the World Cup, at least based on the perspective of these newspapers, seven out of the nine analyzed vehicles dedicated at least one article recognizing the fact that the catastrophic predictions would not be fulfilled and that despite the minor problems, the World Cup would be a success. $\mathrm{BBC}^{7}$ was the fastest one to recognize the event's success, on June 16th, followed by The New York Times ${ }^{8}$ on the next day. On June 21st the Spanishspeaking El País ${ }^{9}$ and the French Le Monde, ${ }^{10}$ and on June 27th, the Guardian ${ }^{11}$ also followed. The most cautious ones were Daily Mail ${ }^{12}$ and El Mundo, ${ }^{13}$ who preferred to draw the balance only in the end of the event, on July 2nd and on July 14th, respectively. It is worth mentioning that El Mundo was the only one to base its opinion on statistics, mentioning that $83 \%$ of the visitors approved the infrastructure during the matches,${ }^{14}$ recognizing the success in a categorical manner, even when mentioning the social inequality in Brazil and FIFA's role. $\mathrm{CNN}^{15}$ preferred to mention the exceptions, making a more sober analysis, weighing the pros and cons of the

${ }^{7}$ Has Brazil proved World Cup doubters wrong? So far so Good (http://www. bbc.com/news/world-latin-america-27866983)

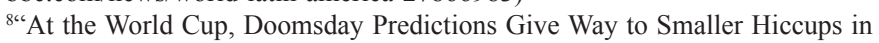
Brazil" (http://www.nytimes.com/2014/06/18/sports/worldcup/at-the-worldcup-doomsday-predictions-give-way-to-smaller-hiccups-in-brazil.html)

${ }^{9}$ No era para tanto: El Mundial discurre mejor de lo esperado. Es cierto. En parte, porque lo esperado era muy malo, una suerte de apocalipsis brasileño en el que poco o nada iba a funcionar como debier (http://deportes.elpais.com/ deportes/2014/06/21/mundial_futbol/1403367068_619144.html)

${ }^{10}{ }^{\prime}$ 'improvisation à la brésilienne se révèle à la hauteur de l'événement. )http:// www.lemonde.fr/coupe-du-monde/article/2014/06/21/1-improvisation-a-labresilienne-se-revele-a-la-hauteur-de-l-evenement $4442780 \quad 1616627 . \mathrm{html}$ ) ${ }^{11}$ World Cup 2014: five things they said would go wrong in Brazil There were gloomy predictions aplenty, from transport chaos to boring football - but at the halfway point only one has come true (http://www.theguardian.com/ football/2014/jun/27/world-cup-2014-five-things-go-wrong)

${ }^{12} 2014$ World Cup is a ball in Brazil as beautiful game wins over sceptics -World Cup 2014 has out priced vast swathes of its host nation. -Stadia, airports and hotels dragged themselves in to shape just in time; FIFA will make a fortune out of the tournament in Brazil http://www.dailymail.co.uk/sport/ worldcup2014/article-2678574/2014-World-Cup-ball-Brazil-beautiful-gamewins-sceptics.html\#ixzz3asmyQJqu.

${ }^{13} \mathrm{Bras}$ ildepaís? ht t p :// w w w. e $1 \mathrm{mundo}$.e s/ opinion/2014/07/14/53c3058fe2704e237b8b458a.html

${ }^{14} \mathrm{http}: / / w w w . e l m u n d o . e s / a m e r i c a / 2014 / 07 / 15 / 53 \mathrm{c} 5467322601 \mathrm{dbc0b} 8 \mathrm{~b} 4592$. html

${ }^{15}$ How did Brazil handle the World Cup? CNN's Shasta Darlington examines Brazil's World Cup hosting performance and looks ahead to the 2016 Olympics (http://edition.cnn.com/videos/world/2014/07/14/pkg-wc-darlington-brazilreport-card.cnn).
World Cup only on its last day. Le Figaro did not draw any balance.

Another element which will be widely discussed under a similar approach for all the newspapers is the inequality. In this sense, the newspapers understand the Brazilian society as extremely unequal in socio economical terms, as well as when it comes to issues like gender and ethnicity. The poverty in Brazil received another approach besides the social criticism, mainly in the case of favelas. Following a tendency of the international tourism, many elements regarding the misery end up assuming a picturesque role. ${ }^{11}$ The communication vehicles will often distance themselves from the perception of the favela as a place of poverty in order to grant them a picturesque image that is a characteristic element of the Brazilian culture. This approach can be seen in articles, such as in BBC's "Rio motorbike ride through favela backstreets. As Brazil basks in the World Cup sunshine, you can get a feel for Rio de Janeiro by taking a hair-raising motorbike ride through its backstreets", ${ }^{16}$ in The Guardian's "Favela residents make World Cup work for them with home stays for fans". ${ }^{17}$ The favela is also one of the preferred places to report the population's commemorations and distresses towards Brazil's performance. ${ }^{18}$

Eventually, the relation between the sport and the country will be a reoccurring theme in all the newspapers. Even recognizing that not all the Brazilians are fanatic for the sport, such as in El Mundo's article "Los brasileños escapan del Mundial hacia Uruguay", ${ }^{19}$ or in CNN's "Brazil 2014: Exploding the myths of sun, samba, soccer", ${ }^{20}$ the newspapers will always fall back on the unique relation between the country and the sport, which may be seen in Daily Mail's article "The colourful lives inside football-mad Brazil". ${ }^{21}$ The approaches will be repeated, emphasizing the sport as an alternative to escape the poverty, ${ }^{22}$ the possible effect that the devastating defeat of the home team could have upon the presidential elections, ${ }^{23}$ as well as that everyone plays football, regardless if in big cities or in the jungle. ${ }^{24}$

Not only is it important what was said, but also what was ignored. the lack of references regarding the Brazilian women seems to be the most significant. In the collective imaginary, as it can be found in the songs of Chico Buarque, Vinicius de Morais and Tom Jobim, there is an idea that the beauty of the women would be detached in international newspapers, with articles that would talk about their body and sexuality, which were frequent topics of the Brazilian tourism agenda, mainly during the $70 \mathrm{~s}$ and $80 \mathrm{~s} .{ }^{12}$ However, this topic was not approached by the analyzed newspapers, counting only with brief and indirect passages in three articles of the Daily Mail, but still without deepening into the subject. Daily Mail stereotyped the Brazilian woman only once, in an article about "Miss Bumbum". ${ }^{25}$ We consider thus that this related image to Brazil has no longer been a

\footnotetext{
${ }^{16} \mathrm{http}: / /$ www.bbc.com/news/world-latin-america-27815624

${ }^{17} \mathrm{http}: / /$ www.bbc.com/news/world-latin-america-27815624

${ }^{18} \mathrm{http}: / /$ www.lemonde.fr/coupe-du-monde/video/2014/07/09/soiree-decauchemar-dans-une-favela-de-rio-de-janeiro_4453819_1616627.html

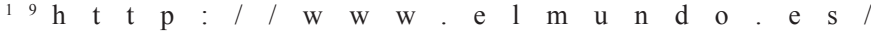
internacional/2014/06/25/53aaf18322601dba658b4590.html

${ }^{20} \mathrm{http}$ //edition.cnn.com/2014/06/13/opinion/brazil-sun-sex-soccer/

${ }^{21} \mathrm{http}: / /$ www.dailymail.co.uk/video/news/video-1099617/The-colourful-livesinside-football-mad-Brazil.html

${ }^{22}$ http://elpais.com/elpais/2014/06/09/planeta_futuro/1402337916_559348. html

${ }^{23} \mathrm{http}$ ://www.lemonde.fr/coupe-du-monde/article/2014/07/09/

la-presidente-du-bresil-ne-croit-pas-que-la-defaite-ravivera-lacontestation_4454278_1616627.html

${ }^{24} \mathrm{http}$ ://lens.blogs.nytimes.com/2014/07/11/world-cup-brazil-mauricio-limalens-blog-worlds-glare/?_r=0

${ }^{25} \mathrm{http}$ ://www.dailymail.co.uk/video/sport/video-1101090/Miss-BumbumBrazil-promotional-trailer.html
} 
central element for the country's promotion abroad, although it is still in the popular culture.

\section{BBC}

BBC produced a significant number of articles related to the World Cup in Brazil, out of which 135 fit in our established parameters. Culture was the most discussed topic, with 57 articles. This aspect received a particular interest in the tourism section, where there was at least one article for each host city discussing its specific characteristics, such as gastronomy, climate, history, touristic attractions and traditions. Provided that the $\mathrm{BBC}$ also has radio stations, there was a privileged space for the Brazilian music. ${ }^{26}$ The second most discussed topic was the infrastructure, with 21 articles. The newspaper reported punctual problems in Brazil, such as the floods in Natal, Recife and in the north of the country, as well as the collapse of a viaduct in Belo Horizonte, which raised the attention of most of the analyzed newspapers. An interesting aspect revealed by the research shows that many of the elements that the Brazilian press, as well as the population, considered as source of great embarrassment for the country, such as traffic, hotels, safety and airports, did not stand out in the same manner in the foreign press. ${ }^{27}$ Traffic was not approached from a negative perspective and was dedicated only one article, whereas airports and hotels, which "surely" represented for the Brazilians and the local medias discussion themes and a negative side of Brazil's image abroad, were not even mentioned. ${ }^{28}$

The World Cup's feasibility was the topic of 19 articles. This category was considered due to the violent protests that first took place during the FIFA Confederations Cup in 2013 and continued to exist in a somewhat intense manner until the end of the World Cup. In the case of the BBC, the protests had particularly little focus, in the sense of doubts regarding how the Brazilians would welcome the foreigners, as well as the protests which took place during the event The problems that were possibly caused by the World Cup were not addressed by this British vehicle as an exclusively responsibility of the Brazilian government, following the present tendency of all other newspapers. FIFA and its business model share the blame for any injustices and inconveniences caused for the Brazilian population. ${ }^{29}$

As it is the case in the other newspapers, BBC highlighted the arrest of FIFA partners connected to the illegal ticket sale.$^{30} \mathrm{With}$ 17 articles, football was the fourth concern of BBC. Although they recognized the deep relation between the country and the sport, the English press did not stress the centrality of the sport in the Brazilians'

${ }^{26}$ World Cup Brazil city guide: Recife; BBC Brazil's Camilla Costa offers an insider's view of the 12 cities hosting matches in this year's Fifa World Cup tournament. Overview Recife. (http://www.bbc.com/news/world-latinamerica-27256168)

${ }^{27}$ World Cup Brazil city guide: Recife; BBC Brazil's Camilla Costa offers an insider's view of the 12 cities hosting matches in this year's Fifa World Cup tournament. Overview Recife. (http://www.bbc.com/news/world-latinamerica-27256168)

${ }^{28}$ World Cup: Natal, Brazil hit by severe weather; Part of Brazil hosting World Cup matches has been hit by severe wet weather and flooding. (http://www. bbc.com/news/world-latin-america-27863948)

${ }^{29}$ Brazil: The Last World Cup? Will Brazil be a game changer for the World Cup? Public anger at the cost of the event isn't going away and Fifa, the organisers, are back in the spotlight over their awarding of the 2022 tournament to Qatar (http://www.bbc.co.uk/programmes/p020jxrf)

${ }^{30}$ World Cup tickets: Ray Whelan and 11 others indicted

Police in Brazil have formally accused 12 people, including the director of a World Cup hospitality company, over alleged illegal ticket sales. (http://www. bbc.com/news/world-latin-america-28240135) life, only mentioning some curiosities and isolated facts. ${ }^{31}$ Social Indicators were not a concern for the BBC. Although there were articles about the expropriation of houses for the World Cup and the racial and social inequality, an improvement of the social indexes is mentioned, as well as official discourses about racial equality. There is a critic against the slave labor in Brazil, the drug market and the favelas. The poverty in Brazil, more specifically the favela, following a tendency of the international tourism and the way the population of developed countries relates to the developing ones, play a picturesque role. Alongside other vehicles, $\mathrm{BBC}$ will often put aside the possible problems to portray the life in these communities in a romantic manner. $^{32}$

\section{CNN}

CNN produced the second lowest number of articles among all the newspapers, with only 42 regarding the World Cup. The American vehicles showed less interest for the event than the British, which may be related to the little influence of the sport in the country. The American group stresses the football in Brazil with 17 articles, talking about how the sport is a central element in the lives of the Brazilians and how it branches out into other areas. ${ }^{33}$ Besides that, this vehicle highlights the celebration, considering that the Brazilian has a unique relation to the sport. ${ }^{34}$ The Social Indexes appear in second place, with nine articles that deal with topics like child prostitution and the expropriations for the event. Although the newspaper talks a lot about the sport and the football culture, CNN seeks to portray the social problems in Brazil a little and also shows concern not to create a stereotyped image of the country. ${ }^{35}$ Brazil's inequality is also underlined, especially in social, political, gender-related and economical dimensions. Other categories were considered minor and can be briefly summarized: in terms of Infrastructure, the collapse of the viaduct in Belo Horizonte was mentioned, as well as the Feasibility of the stadiums in the long-run. Favelas play, such as in other publications, a picturesque role. ${ }^{36}$ There were no references to hotels, traffic, violence against tourists, differently from the other newspapers.

${ }^{31}$ 'Germany' conquer in favela world cup. Footballers from Rio de Janeiro's favelas have staged their own World Cup with 32 teams each replicating nations taking part in the real World Cup. (http://www.bbc.com/news/worldlatin-america-28202708)

${ }^{32}$ Rio motorbike ride through favela backstreets. As Brazil basks in the World Cup sunshine, you can get a feel for Rio de Janeiro by taking a hair-raising motorbike ride through its backstreets. (http://www.bbc.com/news/worldlatin-america-27815624)

${ }^{33}$ Will Brazil's loss hit Dilma's re-election chances?Brazil's humiliating exit from contention in the World Cup at the hands of Germany, and its failure even to take the consolation prize of third place on Saturday, has understandably left Brazilians feeling crushed. Some have gone as far as to describe the host's defeat as a national tragedy. (http://globalpublicsquare.blogs.cnn. com/2014/07/14/will-brazils-loss-hit-dilmas-re-election-chances/).

${ }^{34}$ São Paulo football flavor.The sights and sounds of São Paulo, Brazil, as residents prepare for the World Cup. (http://edition.cnn.com/videos/ sports/2014/06/11/natpkg-world-cup-sao-paulo-football-flavor.cnn).

${ }^{35}$ Brazil 2014: Exploding the myths of sun, samba, soccer. As football's top event kicks off in Brazil, Anthony Pereira dispels some of the myths surrounding the 2014 World Cup's host country -- and its approach to the game it is showcasing. (http://edition.cnn.com/2014/06/13/opinion/brazil-sun-sexsoccer/)

${ }^{36} \mathrm{~A}$ walking tour of Rio's favelas .There's lots for World Cup fans to do in Brazil, including tours of Rio's famous slums, or "favelas." Isa Soares reports. (http://edition.cnn.com/videos/sports/2014/07/02/soares-pkg-world-cuptours-favelas.cnn) 
Table I case, we chose only one in each article, privileging its most relevant meaning

\begin{tabular}{llllllll}
\hline Categories & Culture & Football & Infrastructure & Indicators & Feasibility & Everyday life & Total \\
\hline BBC & 57 & 17 & 21 & 14 & 19 & 7 & 135 \\
CNN & 5 & 17 & 5 & 9 & 5 & 1 & 42 \\
Daily & 24 & 22 & 43 & 17 & 35 & 17 & 158 \\
Guardian & 7 & 3 & 7 & 13 & 19 & 2 & 51 \\
NYT & 8 & 9 & 6 & 6 & 14 & 3 & 46 \\
Le Monde & 16 & 15 & 9 & 11 & 31 & 27 & 109 \\
Le Figaro & 2 & 6 & 6 & 1 & 6 & 2 & 23 \\
El Pais & 12 & 8 & 13 & 16 & 13 & 8 & 70 \\
El Mundo & 14 & 13 & 9 & 16 & 11 & 2 & 65 \\
Total & 145 & 110 & 119 & 103 & 153 & 69 & 699 \\
\hline
\end{tabular}

\section{Daily mail}

The Daily Mail is the one who produced the most, with 158 articles. The biggest concern of the tabloid was the Infrastructure, with 48 texts. Making use of a different style than the other newspapers, the tabloid has the tendency to dedicate several publications to the same topic: there were 4 articles about the collapse of the viaduct in Belo Horizonte and 6 about a trampling incident due to traffic signs. Provided that it is a tabloid, the newspaper stresses police news, mainly cases of violence against tourists, which explains why this category has more articles than the others. ${ }^{37}$

An interesting fact regarding the infrastructure is that a reoccurring theme in the protests against the World Cup, as well as in surveys in Brazil, pointed out the fact that the stadiums would be the biggest problem of the Cup. Daily, unlikely other expectations, was the only newspaper that reported about the infrastructural problems in the stadium. ${ }^{38}$ Following the same journalistic treatment shown by the other newspapers, 35 articles were dedicated to the event's feasibility, given that it addresses themes such as protests and corruption inside FIFA. This last topic was approached in 8 articles, however the content was not a critic towards the federation, but rather the arrest of the involved, stressing the fact that one of them is English.

When it comes to Brazilian culture, the themes are quite generic, without a clear tendency. The newspaper prefers more to approach local curiosities than to discuss the music or regional artistic expressions. ${ }^{39}$ The tabloid's concern is to be fun, so that they would rather portray Brazil's natural landscapes than a more detailled discussion of the Brazilians' lifestyle. Expected to be a central topic, football was only

\footnotetext{
${ }^{37}$ Brazil police investigate rape of American woman. SAO PAULO (AP) Police say they are investigating the alleged rape of an American woman visiting the Brazilian World Cup host city of Cuiaba. The police dep...(http:// www.dailymail.co.uk/news/article-2658070/Police-investigating-rapeAmerican-woman-Brazilian-World-Cup-host-city.html).

${ }^{38}$ Manaus farce: Have ground staff painted pitch green ahead of England's World Cup opener against Italy?Organisers of England's match against Italy appear to have tried to cover up dry grass at the Arena Amazonia by painting the brown patches green. (http://www.dailymail.co.uk/sport/worldcup2014/ article-2656479/Englands-World-Cup-pitch-Manaus-remains-threadbarestate-hours-tick-opening-Group-D-clash-Italy.html).

${ }^{39}$ BRAZIL BEAT: Piranhas? No problem at Manaus beach. MANAUS, Brazil (AP) - Beaches are a big part of life for most Brazilians, and the locals deep in the Amazon jungle are definitely Brazilian. In Manaus, the m... (http:// www.dailymail.co.uk/wires/ap/article-2659242/BRAZIL-BEAT-Piranhas-Noproblem-Manaus-beach.html).
}

the fourth discussion item. The football culture and its centrality in Brazil is based upon the commemorations and the ways the Brazilians root for their team. The newspaper does not give much space to social indexes, not worrying much about potential injustices of the World Cup or about the Brazilians' life. These themes will only be addressed by the arrival of Prince Harry in Brazil and His agenda, which included visits to several social projects. Out of 17 articles of this category, 11 were directly related to any of the activities of the prince. ${ }^{40}$

\section{The guardian}

The Guardian published 51 articles, whose main concern was the event's feasibility. The newspaper criticizes FIFA's attitude, the protests and has a critical reading of the police violence in the demonstrations; the corruption inside FIFA is also a major topic. In terms of Social Indicators, The Guardian is the one which proportionally has the greatest interest in discussing the life conditions of the Brazilians. The themes are diversified, differently from Daily Mail, which turns its attention to the visit of a member of the royal family.

The Guardian approaches topics such as human rights, poverty, deforestation, expropriation of families to build stadiums, indigenous rights and speaks openly about the racism in Brazil and the police violence, not only during the protests, but also in the everyday life. ${ }^{41}$ In the categories Culture and Infrastructure, both with seven articles, general themes are approached; in Culture, Brazilian literature and music are discussed, whereas in Infrastructure the matter of traffic and the big cities is approached. Football was only the third discussed topic, talking about the influence of the sport over the children's life, the importance of the victory for the Brazilian society, approaching as well the political concern, as it could be found to a lesser extent in the discussions about the relation between football and power.

\section{The New York times}

The New York Times published 46 articles that dealt with the

${ }^{40}$ Prince Harry looks at the effects of drug addiction in Brazil - Prince Harry visits Sao Paulo's "Cracolandia" giving him an intimate look at the effects of drug addiction and local efforts to curb and treat the problem (http://www. dailymail.co.uk/video/femail/video-1102005/Prince-Harry-gets-close-lookeffects-drug-addiction-Brazil.html)

${ }^{41}$ Dying to save the Amazonian rainforest.15 Jun 2014: An environmental campaigner is killed every week in Brazil. Jonathan Watts and Karina Vieira travel to Lábrea in the heart of the Amazon to meet the people risking their lives (http://www.theguardian.com/world/2014/jun/15/dying-to-save-amazonianrainforest-brazil). 
themes in a somewhat uniform manner. The Event's Feasibility was the most stressed topic, with 14 articles, and the Social Indexes was the least stressed one, with 6 . In comparison with the other newspapers, the NYT has a more extensive approach. Similar to CNN, the NYT gives more attention to the cultural aspect of the sport in Brazil, with researches about the production of footballs by prisoners and the deep relation between the sport and the Brazilian culture. ${ }^{42}$ In Culture, the newspaper addresses the topic in a generic manner, discussing the country's natural beauties, curiosities and the lifestyle of the population. In terms of Infrastructure and Social Indexes, the newspaper approaches the growth of the Brazilian consumption, the salary increase and considers Brazil the new Latin American richness. $^{43}$

\section{Le monde}

Le Monde, with 109 produced articles, was the non-Englishspeaking newspaper that highlighted the country the most, having, proportionally, discussed the event's feasibility most, with 31 articles. In contrast to the other publications, which in the course of the event stressed the protests less and less, the French newspaper covered the demonstrations until the last day, always worried also in pointing out FIFA's encroachment and the contradictions resulted from an event of this magnitude, mainly in a developing country. The second most numerous categories was the Everyday Life. We firstly considered this category in order to cluster the exceptions, but in this case we gathered 31 articles, mainly because the newspaper published Sérgio Rodrigue's poem "Jules Rimet, Meu Amor"44 (literally: "Jules Rimet, My Love") as a tribute to the host country, dividing it into 24 parts and publishing one each day during the event. Other categories received less attention. In terms of Culture, the newspaper was scarcely dedicated to the tourism and the natural beauties, but turned the attention to different elements of the country, underlining intellectuals such as Sérgio Buarque de Holanda and Roberto da Matta, ${ }^{45}$ as well as traditional names of the Brazilian music. In the other sections, Football, Social Indexes and Infrastructure, the newspaper followed the tendency of the other newspapers, discussing the central role of the sport in the population's life, social inequality and urban planing problems in the big cities, and eventually mentioning the collapse of the viaduct in Belo Horizonte.

\section{Le figaro}

This French newspaper was the least interested in covering the event, with only 27 articles. The categories Culture and Social Indexes where almost neglected, with respectively 2 and 1 article. The newspaper approached the theme in a general manner, focusing rather on facts and producing something wider but on a small scale, discussing the centrality of the football in the life of the Brazilians, some critics against FIFA and occasional problems during the event.

\footnotetext{
${ }^{42}$ Beautiful Game Played With a Gaúcho Flair in Southern Brazil. World Cup 2014: In Porto Alegre, a More Dour Soccer Culture (http://www.nytimes. com/2014/06/21/sports/worldcup/world-cup-2014-in-porto-alegre-a-moredour-soccer-culture.html? $\mathrm{r}=0$ ).

${ }^{43}$ A Highway Doubling as a Haven.Minhocão Represents São Paulo's Crumbling but Welcoming Heart (http:/www.nytimes.com/2014/06/25/sports/ worldcup/minhocao-represents-sao-paulos-crumbling-but-welcoming-heart. html).

${ }^{44} \mathrm{http}$ ://www.lemonde.fr/coupe-du-monde/article/2014/06/12/jules-rimetmeu-amor-par-sergio-rodrigues 4436072 1616627.html

${ }^{45} \mathrm{http}$ ://www.lemonde.fr/economie/article/2014/06/23/quelques-cliches-dubresil_4443467 3234.html
}

\section{El país}

The Spanish newspaper published 70 articles about Brazil, distributed in a relatively equal way. The preferred category was the Social Indexes, with 16 articles. In this group, the vehicle approached more reoccurring themes, which had already been discussed by other newspapers, such as the inequality, the urban infrastructural problems, violence etc. However, as an exception, they approach the country rather positively, making sure to remind the social advancements and the improvements of the previous years, which can be seen in the article "La Copa nos ayuda a descubrir que Brasil ya es un país normal". ${ }^{46}$ Infrastructure and the Event's Feasibility were dedicated 13 articles each.

In the first, the newspaper approached the collapse of the viaduct in Belo Horizonte, such as the others, and highlighted the urban mobility and road conditions, whereas in the second the protests were mentioned with great interest, as well as critics against FIFA. Football, with 8 articles, was similar to the other vehicles, with the metaphor of the football's country repeating itself continuously. In the case of Culture, with 12 articles, the newspaper fled from the pattern and does not stress the country's natural beauties and the host cities, but rather underlines less known aspects of the country and the Brazilian psyche. Finally, Everyday Life had 8 articles, with the Brazilian political life on the spotlight, perhaps because the newspaper has a version in Brazilian Portuguese.

\section{El mundo}

El Mundo, with 65 articles, also focussed on social aspects, with 16 texts. However, the newspaper did not address the most reoccurring topics, rather seeking to discuss specific problems, such as the Bolivian immigration ${ }^{47}$ or the sexual harassment in São Paulo's subway. ${ }^{48}$ The second most present category was Culture, with 14 articles. Similarly, the newspaper approached unusual themes, addressing traditional aspects, such as the nature and the music, curiosities and a rather deepened coverage about the cities where the Spanish team played. With 13 articles, Football was much discussed, with the singularity that this vehicle focussed the least on the theme of Brazil as a football nation, but on the problems that the sport faces inside the country, especially the commercialization, such as in the article "El fútbol y Brasil". ${ }^{49}$ In the other categories, the newspaper made a more conventional approach, discussing problems of urban mobility and underlining the violence against the protesters, in addition to criticizing FIFA's role.

\section{Final considerations}

The World Cup generated a massive interest of the press. During the event's period, an enormous quantity of articles was produced, encompassing the most diverse aspects of the country, containing

\footnotetext{
${ }^{46} \mathrm{http}$ ://internacional.elpais.com/internacional/2014/06/13/ actualidad/1402695566_882258.html

${ }^{47} \mathrm{~h} \mathrm{t} \mathrm{t} \mathrm{p} \mathrm{:} \mathrm{/} \mathrm{/} \mathrm{w} \mathrm{w} \mathrm{w.} \mathrm{e} 1$ m undo.es/internaciona $1 / 2014 / 07 / 04$ /53b702f022601d0e238b456f.html

${ }^{48} \mathrm{~h} \mathrm{t} \mathrm{t} \mathrm{p} \mathrm{:} \mathrm{//} \mathrm{w} \mathrm{w} \mathrm{w.} \mathrm{el} \mathrm{mundo.es/internaciona} 1 / 2014 / 07 / 04$ /53b702f022601d0e238b456f.html

${ }^{49}$ Hace ya tiempo que el fútbol se convirtió en un negocio lleno de jugadas económicas de todo tipo-qué nos van a contar a nosotros-y, como no podía ser de otra manera, este negocio de la pelota mezclado con sentimientos ha ido atrayendo a personajes de diferentes sectores económicos que anteponían sus intereses o bien en temas de recalificaciones o bien en las concesiones, por no hablar de los fichajes y las comisiones.
} 
a great variety of perspectives and perceptions about the Brazilian society and its characteristics, resulting in an amount of information that goes way beyond the context of only one article. In this paper, we selected 699 articles, produced by 9 international media vehicles. Together, they addressed a great deal of subjects, thus exploring several aspects of Brazil, from curiosities about nature to the greater social themes. However, inside this massive amount of information, we could trace some reoccurring topics, with the exaltation of nature being the most present. While the World Cup can be considered a success by these vehicles, despite specific problems, Brazil is still perceived as a country with a series of problems, mainly in the social area, involving violence, inequality and injustice. The problem of inequality was a continuous discussion and all the newspapers understood the Brazilian society as extremely unequal in every aspect, economic, gender-related and in ethnicity. Brazil's image as the land of football was also often mentioned, in this sense, despite the protests and some critics, because the newspapers still comprehend Brazil as uniquely related to the sport. While some perceptions of the country have become stronger, we can also affirm that others were not even mentioned, which is the case with the image of the Brazilian women. Whereas there is still the self-image that the Brazilian women and their sexuality would be reoccurring themes abroad, the article analysis showed that this theme did not call the attention of the analyzed newspapers. The newspapers together presented a great number of aspects that could not be discussed in only one article. However, some reoccurring approaching elements could be noticed, which constituted important sources to understand the transformations of the Brazilian image abroad and, subsequently, of the own self-image of the population.

\section{Acknowledgments}

None.

\section{Conflicts of interest}

The author declares there are no conflicts of interest.

\section{References}

1. Grix Jonathan, Lee D. Soft Power, Sports Mega-Events and Emerging States: The Lure of the Politics of Attraction. Global Society. 2013;27(4):521-536.

2. Preuss Holge R, Christian Alfs. Signaling through the 2008 Beijing Olympics-Using Mega Sport Events to Change the Perception and Image of the Host. European Sport Management Quarterly. 2011;11(1):55-71

3. Manzenreiter Wolfram. The Beijing games in the western imagination of China: The weak power of soft power. Journal of Sport \& Social Issues. 2010; 34(1):29-48.

4. Burke Peter. Os turistas aprendizes. Folha de S. Paulo. Caderno Mais .2006. 12 p.

5. Hue Sheila Moura. Primeiras cartas do Brasil [1551-1555]. Rio de Janeiro: Jorge Zahar; 2006. 147 p.

6. Chaui Marilena. Brasil: mito fundador e sociedade autoritária. 1941. 67 P.

7. Pratt Mary Louise. Os olhos do império - relatos de viagem e transculturação. Bauru: Edusc; 1999. 9 P.

8. Morley David. Belongings Place, space and identity in a mediated world. European journal of cultural studies. 2001;4(4):425-448.

9. Paganotti Ivan. Imagens e estereótipos do Brasil em reportagens de correspondentes internacionais. Rumores-Revista de Comunicação, Linguagem e Mídias. 2009;2(1):125-148.

10. Brasil Antonio. A construção da imagem do Brasil no exterior: um estudo sobre as rotinas profissionais dos correspondentes internacionais. Revista FAMECOS. 2012;19(3):775-794.

11. Freire Medeiros B. A favela que se vê e que se vende: reflexões e polêmicas em torno de um destino turístico. Revista Brasileira de Ciências Sociais. 2007;22(65):61-72.

12. Caetano Rossana. A publicidade e a imagem do produto Brasil e da mulher brasileira como atrativo turístico. In: Anais do Congresso Brasileiro de Ciências da Comunicação. 2004.14 p. 